\title{
Thermostable lipase from Pichia sp. strain RT: Identification, production and characterization
}

\author{
Nur Iznida Mahyon a,b Nurul Izzati Zulkifli ${ }^{\mathrm{b}}$, Nurfarahain Mustaffa Kamal ${ }^{\mathrm{a}, \mathrm{b}}$, Abu Bakar Salleh ${ }^{\mathrm{a}, \mathrm{b}, \mathrm{c}}$, \\ Siti Nurbaya Oslan ${ }^{a, b, c^{*}}$ \\ ${ }^{a}$ Enzyme and Microbial Technology Research Centre, Universiti Putra Malaysia, 43400 UPM Serdang, Selangor, Malaysia \\ ${ }^{b}$ Department of Biochemistry, Faculty of Biotechnology and Biomolecular Sciences, Universiti Putra Malaysia, 43400 UPM \\ Serdang, Selangor, Malaysia \\ 'Institute of Bioscience, Universiti Putra Malaysia, 43400 UPM Serdang, Selangor, Malaysia
}

Received 28th June 2018/ Accepted 21st August 2018

\begin{abstract}
Lipases are hydrolytic enzymes that have been widely used in industries. In order to meet the industrial demands, thermostable lipases which can withstand high temperatures are required. We sought to optimize the lipase production and to characterize the crude lipase from a locally isolated yeast. Yeast from rotten tomato (from Selangor, Malaysia) which has been identified Pichia sp. strain RT and was found to have thermostable lipase. The morphological features of the isolate were analyzed using SEM and TEM. The microscopy examination confirmed that strain RT was a yeast species. Amplification of lipase gene from cDNA library of the Pichia sp. strain RT showed the gene possessed 100\% similarity to the hypothetical protein of Meyerozyma guilliermondii ATCC6260. In addition, the yeast achieved the maximum lipase activity at $30^{\circ} \mathrm{C}$ with $200 \mathrm{rpm}$ after 72 hours of cultivation. The lipase has the optimum temperature at $75^{\circ} \mathrm{C}$ and retained nearly $50 \%$ of residual activity after 30 minutes of pre-incubation at $75^{\circ} \mathrm{C}$. The optimal $\mathrm{pH}$ for $\mathrm{RT}$ lipase was at $\mathrm{pH} 9$ and it highly stable within $\mathrm{pH}$ range $7-10$. Physical parameters and the characteristics of crude lipase in strain RT have been successfully investigated. This finding has given an insight for the use of newly isolated thermostable lipase for industrial applications.
\end{abstract}

Keywords: thermostable, lipase, Pichia sp., optimization, characterization, stability

\section{INTRODUCTION}

Lipases (triacylglycerol acylhydrolases, EC 3.1.1.3) belong to the hydrolase class which catalyse the hydrolysis of triacylglycerides to glycerol and long-chain fatty acids. Lipases are the third largest group of enzymes used for industrial purposes after proteases and carbohydrates. The application of lipases include in biotechnology industry such as detergents formulations, cosmetics and pharmaceutical industry, food, dairy, oleochemical, and paper manufacture. According to Joseph et al. (2008), lipases have the capability to catalyse several reactions such as ester synthesis, interesterification, transesterification, alcoholysis, acidolysis, and aminolysis under controlled conditions. An organic solvent is necessary for these reactions to occur.

Lipases possess some remarkable characteristics, such as their regioselectivity, chemoselectivity, and stereoselectivity which are important to be used in industries. Lipase can be

\footnotetext{
* Author for correspondence: Dr. Siti Nurbaya Oslan, Senior Lecturer, Department of Biochemistry, Faculty of Biotechnology and Biomolecular Sciences, Universiti Putra Malaysia, 43400 UPM Serdang, Selangor, Malaysia. Email - snurbayaoslan@upm.edu.my
} 
produced in large quantities by lipase producing microorganisms including bacteria and fungi. Moreover, the crystal structure of lipase has been reported and the presence of cofactor is not necessary for side reactions (Saxena et al., 1999). These characteristics have made them a generally useful biocatalyst group in organic chemistry.

The sources of lipases are widespread from animals, plants, and microorganisms. Generally, microbial origins of lipases give better significant effects in biotechnology industry since it can be easily manipulated, possibility of high yield, and rapid growth on cultivation using inexpensive media, as well as availability of variety of catalytic activities (Hasan et al., 2006). Microbial enzymes are more stable as compared to animal and plant enzymes, in which their production is much safer and convenient. Among microorganisms, bacterial origin enzymes generally offer higher activities as compared to yeasts, however, they are absent of post-translational modifications which can improve and diversify enzyme functions.

Thermostable enzyme which has the ability to resist chemical denaturation is currently demanded to be used in industry. It also resists permanent inactivation at high temperatures and highly stable in organic solvents during industrial process reactions. A thermostable biocatalyst has many advantages where it can increase the solubility of substrate and products, higher in reactivity and stability, lower viscosity, ultimately reducing the microbial contamination (Hasan et al., 2006). Thermozymes are mostly optimum at elevated temperature in a range of $60-125^{\circ} \mathrm{C}(\mathrm{Li}$ and Zhang, 2005).

Thermostable lipases can be found from bacterial origin such as Bacillus sp., Pseudomonas sp., Geobacillus sp., Streptomyces lividans, Corynebacterium sp., Staphylococcus xylosus, and Thermosyntropha lipolytica (Olusesan et al., 2011; Rathi et al., 2000; Li et al., 2005; Côté and Shareck, 2010; Ray et al., 1999; Khoramnia et al., 2010; Salameh and Wiegel, 2007) and from fungi which include Aspergillus sp., Humicola lanuginose, Penicillium simplicissimum, Antrodia cinnamomea, and Bjerkandera adusta (Saxena et al., 2003; Namboodiri and Chattopadhyaya, 2000; Omar et al., 1987; Gutarra et al., 2009; Lin and Ko, 2005; Bancerz and Ginalska, 2007). Yeast possesses many advantages over bacteria, thus it is much more preferable to be used as a source for proteins. However, fewer number of yeasts with thermostable lipase have been discovered so far. To date, Candida antartica, C. rugosa, Kurtzmanomyces sp., Trichosporon asteroids, and T. coremiiforme were reported to produce thermostable lipases (Domínguez De María et al., 2005; Shaw et al., 1989; Kakugawa et al., 2002; Dharmsthiti and Ammaranond, 1997). Most of them have optimum lipase temperature ranging from $60-90^{\circ} \mathrm{C}$. Therefore, the search for more reliable sources for thermostable lipases from yeast is necessary to meet the industrial demand.

In 2012, Oslan et al. isolated a mesophilic yeast from rotten tomato, and the yeast was identified according to rDNA ITS region and biochemical tests. The isolated RT showed 99\% similarity to Pichia guilliermondii species and has been classified as Pichia sp. strain RT (GenBank accession number: JQ073892). However, the authors did not perform morphological examination on their isolated yeast. Their result have also shown that the host is capable of producing intracellular thermostable lipase when assayed at $70^{\circ} \mathrm{C}$, but in low level of expression. To better understand this lipase, this study sought to investigate the morphology of Pichia sp. strain RT, identify the lipase sequence, optimize the carbon and nitrogen sources for the yeast to grow, followed by determination of the physical parameters to optimize the lipase production and characterize the crude thermostable lipase produced from the host. This study is important to characterize the lipase prior to usage in industrial application.

\section{MATERIALS AND METHODS}

Maintenance and cultivation of stock culture. Pichia strain RT was obtained from Oslan et al. (2012) at Institute of Bioscience, Universiti Putra Malaysia. Cultivation was carried out in YPD plate containing $(\mathrm{w} / \mathrm{v}): 1 \%$ yeast extract, $2 \%$ peptone, $2 \%$ dextrose, and $2 \%$ agar at $30{ }^{\circ} \mathrm{C}$ for 3 days. Then single colony was inoculated into $10 \mathrm{ml}$ YPD broth (same composition as YPD agar but without agar) and incubated at $30^{\circ} \mathrm{C}, 200 \mathrm{rpm}$ for 24 hours.

Scanning electron microscopy (SEM). The yeast culture was harvested by centrifugation followed by SEM sample preparation according 
to a standard laboratory method (Microscopy Unit, Institute of Bioscience, UPM, Serdang). Pellet was fixed in $2.5 \%$ glutaraldehyde for 46 hours at $4^{\circ} \mathrm{C}$ and centrifuged at $5 \times$ g, 5 minutes. Next, the pellet was washed with $0.1 \mathrm{M}$ sodium cacodylate buffer for three times within 10 minutes. Post-fixation was done in $1 \%$ osmium tetraoxide for 2 hours at $4{ }^{\circ} \mathrm{C}$, followed by washing step. The fixed cells were dehydrated in a series of increasing acetone concentrations of $35 \%, 50 \%$, $75 \%$ and $95 \%$ for 10 minutes and $100 \%$ for 15 minutes, for three times. The cell suspension was pipetted onto an aluminium foil that has been coated with albumin. Specimen was transferred into specimen basket and put into critical dryer for about half an hour for a critical drying step. Mounting was done by fixing the specimen onto the stub. Prior to viewing, the specimen was coated by using gold, and then observed on SEM machine JEOL JSM 6400.

\section{Transmission electron microscopy (TEM).}

Primary fixation for TEM was prepared according to SEM method, except after fixation, the pellet was resuspended in animal serum. The sample was allowed to clot for an overnight and diced into $1 \mathrm{~mm}^{3}$, fixed in $2.5 \%$ glutaraldehyde for $1-2$ hours at $4^{\circ} \mathrm{C}$. Next, the sample was washed until dehydration according to SEM method, without centrifuging for each step. After the dehydration, infiltration with acetone and resin mixture (in ratio) was done as follows at respective durations; 1:1 (1 hour), 1:3 (2 hours), 0:1 (overnight), 0:1 (2 hours) and slow rotation was applied during the incubation time. The specimen was placed into beam capsules for embedding step and was filled up with resin. Polymerization was done in an oven at $60^{\circ} \mathrm{C}$ for $24-48$ hours. A thick sectioning was done using an ultramicrotome to cut $1 \mu \mathrm{m}$ thick sections and ultrathin sectioning to select the area of interest. Finally, the sample was stained with uranyl acetate for 15 minutes prior viewing under TEM (Hitachi H-7100).

Hidden Markov Model (HMM) search. A model harbouring thermostable lipase sequences from different sources of microorganisms was built using multiple sequence alignment (MSA). Then, the model was used to find the lipase genes from the yeast proteome using HMM command.
The model was run to search against $P$. guilliermondii strain ATCC 6260 proteome with a cut off E-value $=0.01$. Then, the results (hits) of the HMM search was observed using ATOM software (https://atom.io).

cDNA synthesis. Isolation of total RNA from Pichia strain RT was performed using Presto Mini RNA Extraction Kit (Geneaid, UK). The synthesis of DNA using RNA template via transcription produced complementary DNA (cDNA). Transcript II One-step gDNA Remover and cDNA synthesis Supermix (Transgen, Beijing) kit was used to convert the RNA template into cDNA library. $250 \mathrm{ng} / \mu \mathrm{l}$ of RNA template was mixed with $1 \mu \mathrm{l}$ of transcript enzyme mix, 1 $\mu l$ of $\mathrm{gDNA}$ remover, $1 \mu \mathrm{l}$ of random primer and $10 \mu \mathrm{l}$ of reaction mix. The mixture was heated in the PCR machine at $42^{\circ} \mathrm{C}$ for 30 minutes and later at $85^{\circ} \mathrm{C}$ for 5 seconds to stop the reaction.

Amplification of lipase gene. Primers were designed using hit (lipase sequence) from the HMM search as follows; forward primer A5DQV0: 5'-ATGCTGCAAGTCGGTAGA-3' and reverse primer A5DQV0: 5'CTAAAATCCATGT'TATATAAAT'TGGC-3'. PCR was performed by mixing $50 \mathrm{ng} / \mu \mathrm{l}$ of the strain RT cDNA, $0.5 \mu \mathrm{l}$ each of the $10 \mathrm{mM}$ forward and reverse primer, 12.5 $\mu$ l PCR mastermix and autoclaved distilled water up to 25 $\mu \mathrm{l}$ for one reaction. The cycling program was as follows: $94^{\circ} \mathrm{C}$ for 2 minutes followed by 30 cycles of $94^{\circ} \mathrm{C}$ for 30 seconds, $50^{\circ} \mathrm{C}$ for 30 seconds, and $72^{\circ} \mathrm{C}$ for 1 minute. Then, the amplified PCR product was purified (Geneaid PCR Cleanup Kit, UK).

Lipase assay. Colorimetric assay was done using a copper reagent as described by Kwon and Rhee (1986) to monitor the activity of crude lipase enzyme. Copper reagent was prepared by adjusting $5 \%(\mathrm{w} / \mathrm{v})$ of copper (II) acetate-1hydrate to $\mathrm{pH} 6.1$ with pyridine. Substrate (olive oil, Bertoly, Italy) was prepared by emulsifiying it with $50 \mathrm{mM}$ glycine- $\mathrm{NaOH}$ buffer $(\mathrm{pH}$ 9) with an equal volume 1:1 ratio $(\mathrm{v} / \mathrm{v})$. Olive oil was chosen as the substrate as it is a natural oil that is rich in long chain fatty acids. The reaction was started by addition of $2.5 \mathrm{ml}$ of substrate emulsion, $1 \mathrm{ml}$ of crude enzyme and $20 \mu \mathrm{l}$ of $20 \mathrm{mM} \mathrm{CaCl}_{2}$ together 
in a vial with an agitation speed of $200 \mathrm{rpm}$ for 30 minutes at $70^{\circ} \mathrm{C}$. Then, $1.0 \mathrm{ml}$ of $6 \mathrm{~N} \mathrm{HCl}$ was added to stop the reaction. Formation of fatty acids was extracted by an addition of $5 \mathrm{ml}$ isooctane, vortexed for 30 seconds followed by allowing the reaction to settle down for 15 minutes. The upper layer $(4 \mathrm{ml})$ containing the fatty acids was transferred to a test tube and mixed vigorously for 30 seconds with $1 \mathrm{ml}$ of copper reagent for the colorimetric detection of free fatty acid. Then the reaction was allowed to settle down for at least 1 hour. The absorbance was recorded at $\mathrm{OD}_{715 \mathrm{~nm}}$ using UV-Visible spectrophotometer. One unit (U) of lipase activity was defined as the rate of fatty acid formation ( $\mu \mathrm{mol}$ per minutes) under standard assay conditions.

Protein content. The protein content of the enzyme solution was measured using Bovine Serum Albumin (BSA) as a protein standard (Bora et al., 2007). A mixture containing $20 \mu \mathrm{l}$ of crude enzyme and $1 \mathrm{ml}$ Bradford reagent (Bio-Rad) was vortexed for few seconds and set aside for 10 minutes. Absorbance was monitored at $\mathrm{OD}_{595 \mathrm{~nm}}$ and expressed in milligram per millilitre $(\mathrm{mg} / \mathrm{ml})$.

\section{Optimization of crude lipase production.}

Physical parameters such as effect of incubation temperature and time followed by agitation speed were optimized. Single colony of strain RT was inoculated into $10 \mathrm{ml}$ YPD broth and incubated at $30^{\circ} \mathrm{C}$, for $24 \mathrm{~h}\left(\mathrm{OD}_{600 \mathrm{~nm}}=15\right)$ with an agitation rate of $250 \mathrm{rpm}$. Next, $1 \mathrm{ml}$ of culture was inoculated into $100 \mathrm{ml}$ of YPD media (w/v): 1\% yeast extract, $2 \%$ peptone, $2 \%$ dextrose in $500 \mathrm{ml}$ conical flask. Cell was harvested after 72 hours of incubation time by centrifugation at $3,000 \mathrm{x}$ g, at $4^{\circ} \mathrm{C}$, for $10 \mathrm{~min}$. Then, the pellet was resuspended in $5 \mathrm{ml}$ of $50 \mathrm{mM}$ glycine- $\mathrm{NaOH}(\mathrm{pH}$ 9) and sonicated for 5 minutes with 30 seconds intervals to break the cell. Centrifugation of homogenate was conducted at $10,000 \times \mathrm{g}$, at $4^{\circ} \mathrm{C}$ for 10 minutes. Finally the supernatant was used to monitor the crude lipase activity in strain RT.

Effect of incubation temperature. Optimal incubation temperature for a maximum lipase production was monitored at the following temperatures: $28^{\circ} \mathrm{C}, 30^{\circ} \mathrm{C}, 32^{\circ} \mathrm{C}$, and $34^{\circ} \mathrm{C}$ with $250 \mathrm{rpm}$ agitation rate for 72 hours.
Effect of incubation time. Cultivation condition was performed at $30^{\circ} \mathrm{C}$ under shaking conditions of $250 \mathrm{rpm}$. $1 \mathrm{~L}$ of YPD broth was prepared in 5 L conical flask. A $20 \mathrm{ml}$ of culture was collected every 12 hours interval for 6 days. The culture was harvested by centrifugation at $3,000 \times \mathrm{g}, 4^{\circ} \mathrm{C}$ for 10 minutes and resuspended with $5 \mathrm{ml}$ of $50 \mathrm{mM}$ glycine- $\mathrm{NaOH}$ buffer ( $\mathrm{pH} 9)$. Next, sonication for 2.5 minutes was conducted to break the cell. The homogenate was then centrifuged at $10,000 \mathrm{x} g$ for 10 minutes at $4^{\circ} \mathrm{C}$. The supernatant was kept at $-80^{\circ} \mathrm{C}$ and lipase activity was monitored.

Effect of agitation rate. Different agitation rates were performed in an incubator shaker to check for effect of agitation on lipase production by strain RT. Several agitation rates were chosen (150 $\mathrm{rpm}, 200 \mathrm{rpm}, 250 \mathrm{rpm}$, and $300 \mathrm{rpm})$. The cultures were cultivated for 72 hours at $30^{\circ} \mathrm{C}$ followed by an enzymatic assay.

Optimum temperature and $\mathbf{p H}$. The optimum temperature for lipase activity for strain RT was evaluated over the range of $45^{\circ} \mathrm{C}$ to $90^{\circ} \mathrm{C}$. Initially the cells were harvested and centrifuged. Then, the crude lipase was assayed at different temperatures and $\mathrm{pH}$ (for the buffer and emulsion). The lipase assay (in triplicates) was performed according to the temperature range for 30 minutes. For optimum pH determination, a 20 $\mathrm{ml}$ of culture was harvested and the pellet was resuspended in $5 \mathrm{ml}$ respective buffers with different $\mathrm{pH}$ (4-12); $50 \mathrm{mM}$ acetate buffer ( $\mathrm{pH} 4$ 6), $50 \mathrm{mM}$ sodium phosphate buffer ( $\mathrm{pH}$ 6-8), 50 $\mathrm{mM}$ Tris- $\mathrm{HCl}$ buffer ( $\mathrm{pH} 8-9), 50 \mathrm{mM}$ glycine$\mathrm{NaOH}\left(\mathrm{pH}\right.$ 9-11), and $50 \mathrm{mM} \mathrm{Na}_{2} \mathrm{HPO}_{3} / \mathrm{NaOH}$ buffer $(\mathrm{pH} 11-12)$ at $50^{\circ} \mathrm{C}$, followed by sonication for 2.5 minutes. Then, the homogenate was centrifuged at $10,000 \mathrm{xg}, 4^{\circ} \mathrm{C}$ for $10 \mathrm{~min}$. The emulsion for lipase assay was prepared with the respective buffers for each $\mathrm{pH}$.

Thermostability and pH stability. A $0.7 \mathrm{mg}$ enzyme was incubated at temperature $60^{\circ} \mathrm{C}, 65^{\circ} \mathrm{C}$, $70^{\circ} \mathrm{C}, 75^{\circ} \mathrm{C}$, and $80^{\circ} \mathrm{C}$ for 1 hour prior to enzyme assay. The lipase assay was performed at $75^{\circ} \mathrm{C}$ every 15 minutes interval and the relative activity was determined. For $\mathrm{pH}$ stability, a $20 \mathrm{ml}$ of culture was harvested and resuspended with $3 \mathrm{ml}$ of $50 \mathrm{mM}$ Tris-HCl buffer ( $\mathrm{pH}$ 9), followed by sonication and centrifugation. A $2 \mathrm{mg}$ (in $0.2 \mathrm{ml}$ ) crude enzyme was added with $0.8 \mathrm{ml}$ respective 
buffers: $50 \mathrm{mM}$ acetate buffer ( $\mathrm{pH} 4-6), 50 \mathrm{mM}$ sodium phosphate buffer ( $\mathrm{pH}$ 6-8), $50 \mathrm{mM}$ Tris$\mathrm{HCl}$ buffer (pH 8-9), $50 \mathrm{mM}$ glycine- $\mathrm{NaOH}$ (pH 9-11), and $50 \mathrm{mM} \mathrm{Na} \mathrm{HPO}_{3} / \mathrm{NaOH}$ buffer ( $\mathrm{pH}$ 11-12) and was pre-incubated at $50^{\circ} \mathrm{C}$ for 30 minutes with $200 \mathrm{rpm}$. Then, the lipase assay was performed at $75^{\circ} \mathrm{C}$ with the optimum buffer (Tris- $\mathrm{HCl}, \mathrm{pH}$ 9).

\section{RESULTS AND DISCUSSION}

Electron microscopy examination. To classify a microbe in the fungal kingdom, rRNA identification alone is inadequate, therefore morphological analysis is vital (Ando and Nakamura, 2000; Hyde et al., 2010). Besides, only partial characterization has been done to strain RT in previous experiment by Oslan et al., (2012). SEM was performed to investigate the surface structure, giving the three-dimensional images of a specimen. From Figure 1 (a) and (b), the budding cells can be clearly observed which it is an asexual reproduction in yeast. From the budding cells shown, it indicated that cells were actively growing. By comparison to other SEM results from Pichia sp., the similar pattern of budding was observed. Based on Figure 1 (b), the size of Pichia sp. strain RT under 10,000X magnifications is about $0.6-1 \mu \mathrm{m}$. The size of cell for strain RT was quite small as compared to other yeast species such as $P$. maclurae, $P$. misumaiensis and Candida mycetangii, where the size of cells were about 2.5-5 $\mu \mathrm{m}$ (Kurtzman, 2000). However, the size of cells as compared to $P$. guilliermondii were between 0.5-1 $\mu \mathrm{m}$ (Mukherjee et al., 2014; Beres et al., 2011).

TEM gives the details in internal dimension such as cellular structure of cells at very high magnifications. As shown in Figure 1 (c), the size of Pichia sp. strain RT was 0.5-0.9 $\mu \mathrm{m}$ with 30,000X magnification. Yeast has been classified as fungus and it has a cell wall as part of its structure. From Figure 1 (c) and (d), it can be clearly observed that the cell wall $(\mathrm{CW})$ and cell membrane (CM) are present. On the other hand, the intracellular organelles could not be observed clearly, which might be due to problems during the fixation step (Osumi, 1998). In this experiment, strain RT was post-fixed with osmium tetroxide which might not penetrate well into the thick CW. The osmium tetroxide should be replaced with potassium permanganate for a better result. We did not proceed with potassium permanganate because the focus of this experiment was only to confirm that strain RT belongs under a yeast species. It has been classified under the fungal kingdom because of the presence of CW in their structure, which is absent in bacterial cell structure. Besides, yeast is a single-cell and the type of reproduction for Pichia sp. strain RT is by multilateral budding (MB), as shown in Figure 1 (c) and (d) (Walker, 1998). The thickness of the CW for strain RT was really thin, about $40-60 \mathrm{~nm}$. As compared to other yeast species, Candida albicans has approximately $400 \mathrm{~nm}$ (Osumi, 1998). Whereas for Schizosaccharomyces pombe and Saccharomyces cerevisiae, sizes up to $200 \mathrm{~nm}$ and $90 \mathrm{~nm}$, respectively, have been recorded (Osumi et al., 1989; Smith et al., 2000). As reported by Klis et al. (2006), the thickness and composition of $\mathrm{CW}$ vary depending on the growth temperature, oxygen levels, external $\mathrm{pH}$ and the composition of growth medium.

This analysis reported the features of microscopic morphological characteristics of yeast strain RT. The existence of rigid CW (Figure 1 (c) and (d)), and asexual reproduction by budding (Figure 1 (a) and (b)) classified the yeast strain RT under unicellular fungi. The dissimilarity with prokaryotic cell structure is that they lack CW (except for Gram-negative bacteria) and the mode of reproduction is by binary fission.
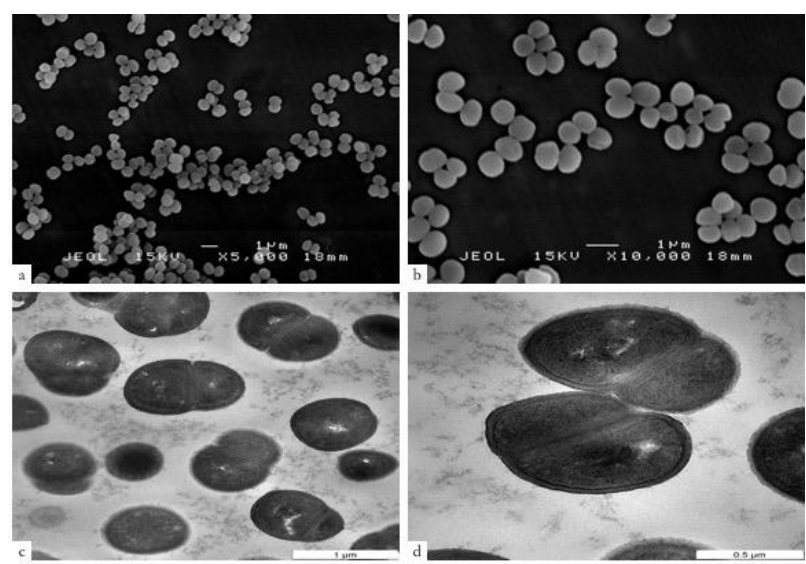

Figure 1. SEM and TEM of Pichia sp. strain RT. a) SEM under 5,000X magnification (scale bar: 1 $\mu \mathrm{m}$ ); b) SEM under 10,000X magnification (scale bar: $1 \mu \mathrm{m}$ ); c) TEM under 30,000X magnification 
(scale bar: $1 \mu \mathrm{m}$ ); d) TEM under 60,000X magnification (scale bar: $0.5 \mu \mathrm{m}$ ).

Amplification of a lipase gene and bioinformatic analysis. Using HMM search tool, A5DQV0 (uncharacterized protein) was revealed as one hit from $P$. guilliermondii strain ATCC6260. The PCR result obtained was $1 \mathrm{~kb}$ from cDNA of Pichia strain RT (Supplementary Figure 1).

Sequence analysis was performed using Basic Local Alignment Search Tool (BLAST). The results showed that RT lipase sequence is $100 \%$ similar to the hypothetical protein PGUG_05651 (Meyerozyma guilliermondii ATCC 6260). The BLAST result also showed that RT lipase was 55\% similar to triacylglycerol lipase from Candida albicans, indicating that it is within the gene lipase family. The sequence has to be obtained as the sequence could provide more information and knowledge to facilitate the identification of the Picbia strain RT for industrial applications.

\section{Optimization of incubation temperature.}

Figure 2 (a) shows the qualitative screening of RT lipase produced from strain RT. Fluorescent yellow around the colony indicates the presence of lipolytic activity. Temperature is one of the most crucial parameters for lipase production in an organism. A host needs to be grown at its optimum growth temperature in order to produce the enzyme optimally. The effect of temperature on lipase production by strain RT was further examined at $28^{\circ} \mathrm{C}, 30^{\circ} \mathrm{C}, 32^{\circ} \mathrm{C}$, and $34^{\circ} \mathrm{C}$ in conical flasks. As shown on Figure 2 (b), the optimum crude lipase production from strain RT was recorded at $30^{\circ} \mathrm{C}$. Different relative activities of enzyme can be clearly seen with a temperature variation of $2^{\circ} \mathrm{C}$, indicating that temperature control could be a critical parameter which greatly influences the enzyme production. As reported by De Almeida et al. (2013), enzyme production has shown a variation with $2.5^{\circ} \mathrm{C}$ which can be correlated to our finding which small variation of temperature can affect enzyme production. The optimum growth temperature for most lipase microorganism producers was around $25^{\circ} \mathrm{C}$ and $30^{\circ} \mathrm{C}$ (Kumar et al., 2011).

Optimization of incubation time. The incubation time for enzyme production is administered by the conditions of culture and the growth rate. The lipase activity was increased with the increase of incubation time starting from the first 12 hours. The maximum activity of lipase was observed after 72 hours. Figure 2 (c), shows the time course study of strain RT, where the production of lipase was found to be optimized at 72 hours incubation, which was similar to Yarrowia lipolytica NRRL Y-2178 (Lee et al., 2007). Prolonged incubation time has decreased the enzyme activity. No lipase activity was detected at 0 hour of incubation.

Optimization of agitation rate. Agitation is important especially in yeast culture. Slow agitation might cause insufficient dissolved oxygen to the culture for propagation, while high agitation speed induces shear stress to the cell, resulting in low enzyme activity (Lee et al., 2007). In addition, sufficient agitation rate aids in removal of $\mathrm{CO}_{2}$ from the culture environment and increases the nutrition intake by yeast. Figure 2 (d) shows the effect of different agitation rates on lipase production in strain RT at various shaking speeds ranging from 150 to $300 \mathrm{rpm}$.

Statistical analysis for lipase production at 200 $\mathrm{rpm}$ and $250 \mathrm{rpm}$ were not significant. The relative activity for lipase production with agitation rates of $200 \mathrm{rpm}$ and $250 \mathrm{rpm}$ after incubation for 72 hours were $95.55 \%$ and $100 \%$, respectively. Lower shaking rate at $150 \mathrm{rpm}$ indicated the lowest relative activity with $9.12 \%$. Meanwhile, higher shaking rate (300 rpm) caused the reduction of about $60 \%$ of relative activity. Thus, optimum agitation rate for lipase production by strain RT was found at $200 \mathrm{rpm}$. 

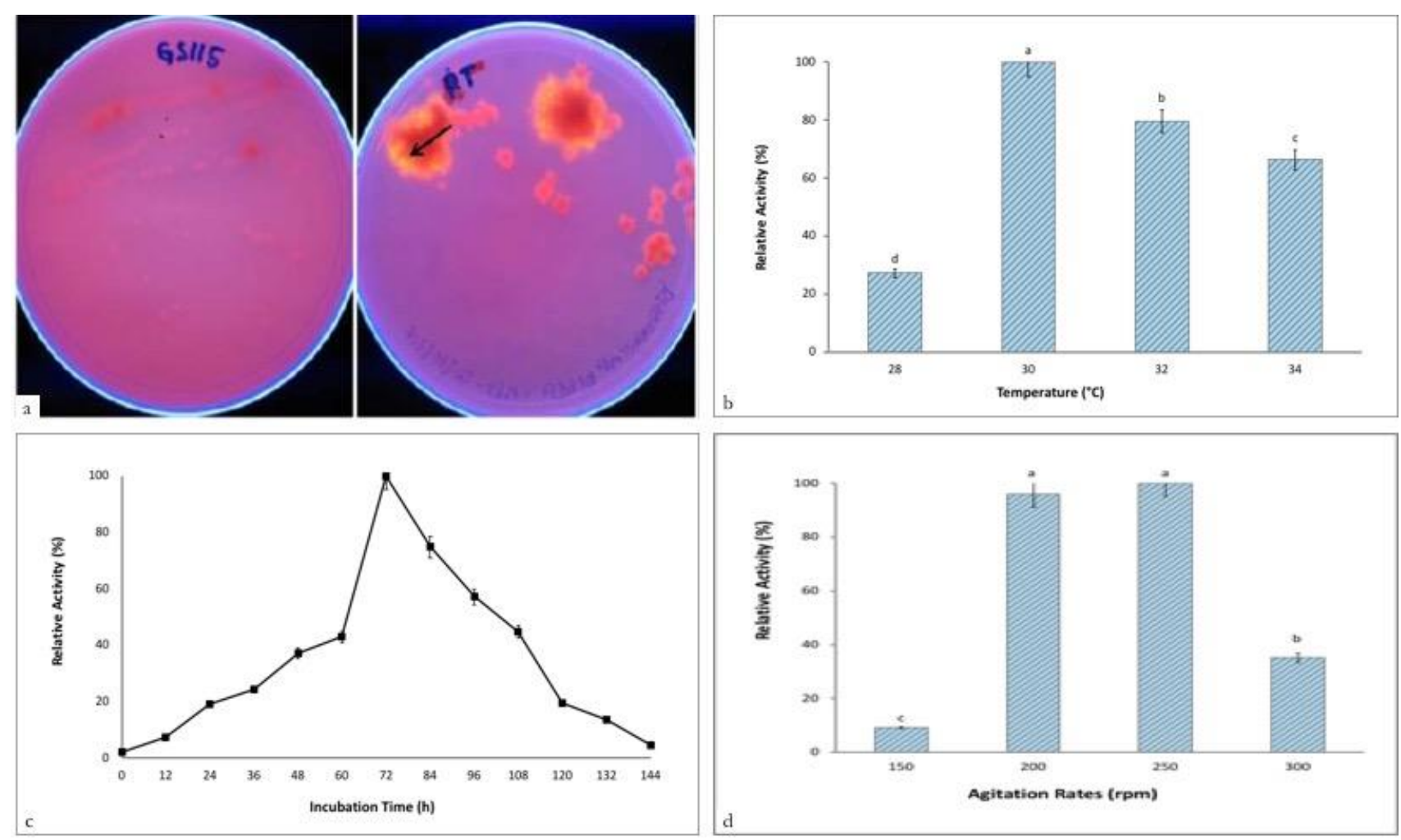

Figure 2. Physical effects on lipase production by strain RT. a) Screening of RT lipase using rhodamine $\mathrm{B}$ plate. The fluorescent colour showed lipase production on RT lipase sample (black arrow). The negative control, SO, showed no fluorescent colour indicating no lipase expression from the sample. b) Maximum lipase production was determined at various temperatures: $28^{\circ} \mathrm{C}, 30^{\circ} \mathrm{C}, 32^{\circ} \mathrm{C}$, and $34^{\circ} \mathrm{C}$. c) Culture media were incubated at $30^{\circ} \mathrm{C}$ with different shaking rates as follows: $150,200,250$ and $300 \mathrm{rpm}$ for 72 hours. d) The effect of incubation time on lipase production was determined by checking for enzyme activity at various times with 12 hours interval for 144 hours.

\section{Determination of optimal temperature and} $p H$ for $\boldsymbol{R T}$ lipase. Thermostable lipases have always been preferred in industrial processes since it can withstand high temperatures. The quantitative screening determined the lipase activity by measuring fatty acids formation. As shown in Figure 3 (a), lipase activity gradually increased with temperatures from $60^{\circ} \mathrm{C}$ to $75^{\circ} \mathrm{C}$. Optimum crude lipase activity for strain RT was 2002). To date, no Pichia sp. strain was reported to have thermostable lipase behavior.

$\mathrm{pH}$ is one of the crucial parameters for enzymes to be active. The active site of an enzyme composed of ionizable groups which were presented in diverse structural conformations. Suitable ionic condition ( $\mathrm{pH}$ of environment) is desired in order to maintain 3D conformation of enzyme's active site to catalyze the reaction. Crude lipase was assayed at various $\mathrm{pH}$ for 30 minutes. Figure 3 (b) shows the effect of $\mathrm{pH}$ on crude lipase activity of strain RT where the optimum $\mathrm{pH}$ for enzyme activity was discovered recorded at $75^{\circ} \mathrm{C}$ with $100 \%$ relative activity. The second highest lipase activity was determined at $70^{\circ} \mathrm{C}$ with $88.8 \%$ relative activity. As reported by Kakugawa et al. (2002), this is the normal temperature recorded for other thermostable enzymes in yeasts. Kurtzmanomyces sp. was recorded to have a thermostable lipase with the optimum temperature of $75^{\circ} \mathrm{C}$ (Kakugawa et al.,

at $\mathrm{pH} 9$ with $100 \%$ relative activity. Lipase activity was notably decreased at $\mathrm{pH} 10$ to $\mathrm{pH} \mathrm{12,}$ probably due to enzyme denaturation at high alkaline condition. However, the relative activities at $\mathrm{pH} 7$ and $\mathrm{pH} 8$ were $45 \%$ to $53 \%$, respectively. Other lipases from different sources possessed lower $\mathrm{pH}$ for optimum condition of enzyme activity such as $P$. guilliermondii $\mathrm{N} 12 \mathrm{c}(\mathrm{pH} 7.5)$, Candida antarctica and Yarrowia lipolytica $\mathrm{N} 9 \mathrm{a}(\mathrm{pH}$ 8.0), and Aureobasidium pullulans HN2.3 (pH 8.5) (Wang et al., 2007). 
Determination of temperature and $\mathrm{pH}$ stability for RT lipase. Stability of lipase in terms of temperature was investigated after incubation at different temperatures ranging from $60^{\circ} \mathrm{C}$ to $80^{\circ} \mathrm{C}$ with 15 minutes interval, for 1 hour. Lipase from strain RT was relatively thermostable because the activity of lipase was at $75^{\circ} \mathrm{C}$ and the activity was retained for 30 minutes, with nearly up to $50 \%$ of its initial activity as shown in Figure 3 (c). At $80^{\circ} \mathrm{C}$, lipase started to lose its activity for more than $70 \%$ after 30 minutes incubation. Another report showed that Bacillus sp. LBN4 with $65^{\circ} \mathrm{C}$ optimum temperature could retain $80 \%$ of its initial activity at $80^{\circ} \mathrm{C}$ for 10 minutes (Bora and Kalita, 2007). A lipase-producing fungus (Geotrichum-like R59) was found to be stable after 1 hour incubation at $60^{\circ} \mathrm{C}$ (Ginalska et al., 2007).

By referring to Figure 3 (d), the crude lipase of strain RT was reported to be relatively stable at alkaline condition (pH 8 to 10 ) with up to $60 \%$ of relative activity. The optimum lipase activity was reported at $\mathrm{pH} 9$, indicating that their stability could have a great potential in detergent industry. However, the relative activity of enzyme at $\mathrm{pH}$ below 7 and above $\mathrm{pH} 10$ was significantly low due to the improper conformational of their active site, thus resulting in irreversible enzyme inactivation.
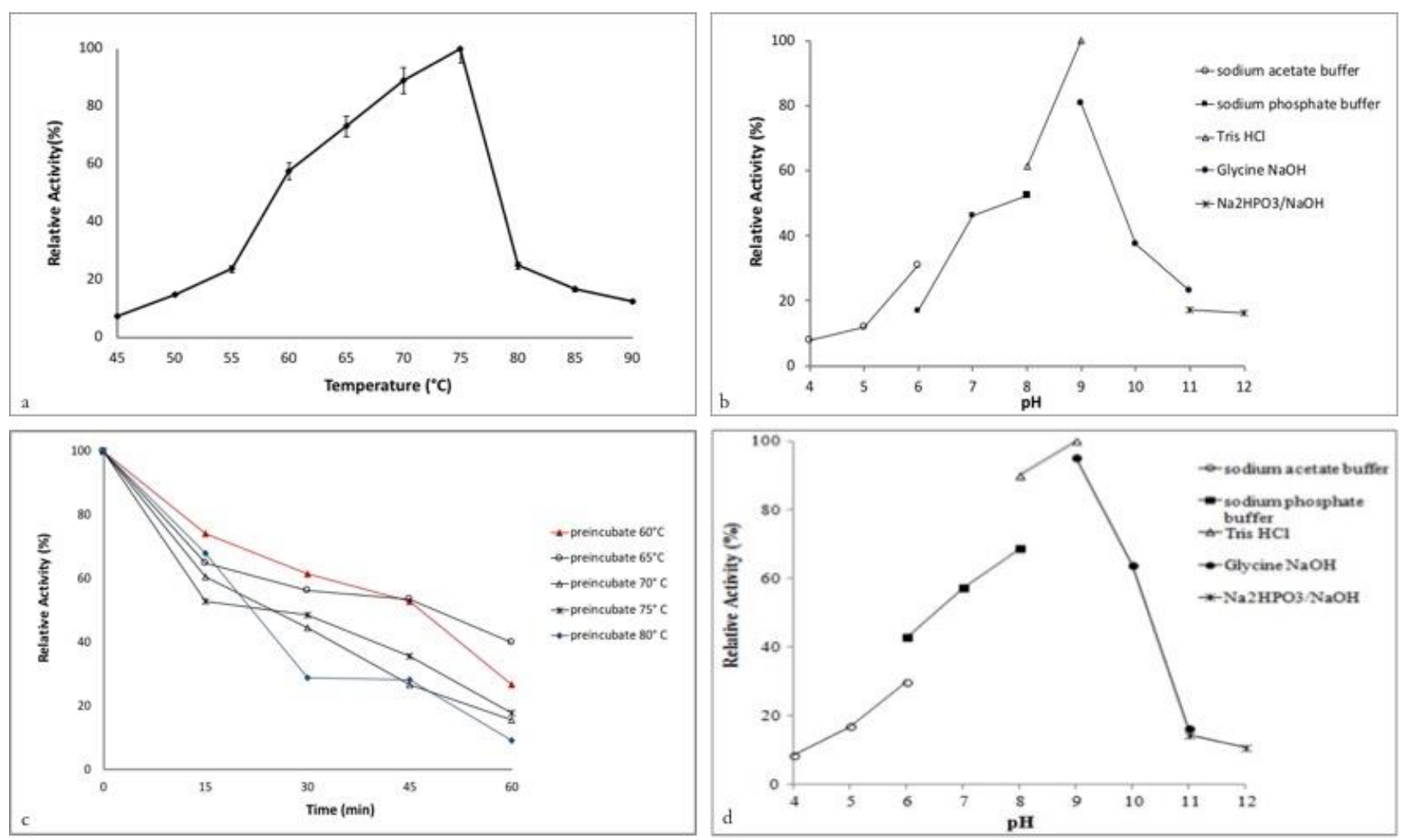

Figure 3. Stability test on lipase production by strain RT. a) Effect of temperature. Lipase activity was monitored at various temperatures $\left(45^{\circ} \mathrm{C}\right.$ to $90^{\circ} \mathrm{C}$ with $5^{\circ} \mathrm{C}$ interval); b) Effect of $\mathrm{pH}$. The enzyme was assayed at different $\mathrm{pHs}\left(\mathrm{pH} 4\right.$ to $\mathrm{pH} 12$ ) using respective buffers at $75^{\circ} \mathrm{C}$ for $30 \mathrm{~min}$; c) Thermostability profile. The enzyme was incubated at various temperature of $60^{\circ} \mathrm{C}, 65^{\circ} \mathrm{C}, 70^{\circ} \mathrm{C}, 75^{\circ} \mathrm{C}$ and $80^{\circ} \mathrm{C}$ for 1 hour followed by lipase assay $\left(\right.$ at $75^{\circ} \mathrm{C}$ with glycine $\mathrm{NaOH}$ buffer, $\mathrm{pH}$ 9) and $\mathbf{d}$ ) $\mathrm{pH}$ stability. The enzyme was incubated at various $\mathrm{pHs}$ ranging from $\mathrm{pH} 4$ to $\mathrm{pH} 12$ using respective buffers at $50^{\circ} \mathrm{C}$ for 30 minutes followed by assay using Tris- $\mathrm{HCl}(\mathrm{pH} 9)$ at $75^{\circ} \mathrm{C}$.

\section{CONCLUSION}

In conclusion, the lipase from Pichia sp. strain RT has been successfully identified, optimized and characterized. The morphological features of the yeast were also investigated using SEM and TEM. The RT lipase has been identified as thermostable lipase based on its optimal activity at high temperature. Potentially, it can be used in many 
industrial applications because this microbial source lipase is halal and acceptable for many followers. Molecular cloning of RT lipase into an expression host such as Escherichia coli or Pichia pastoris can improve the yield.

\section{ACKNOWLEDGEMENTS}

Authors would like to thank Universiti Putra Malaysia for Putra Grant (project number GPIPS/2017/9572500), which was awarded to the last author and Graduate Research Fellowship, which was awarded to the first and third authors.

\section{REFERENCES}

Ando, K. and Nakamura, N. 2000. Pseudosigmoidea: a new genus for a hypomycete (ATCC 16660) formerly identified as Sigmoidea prolifera. The Journal of General and Applied Microbiology 46:51-57.

Bancerz, R. and Ginalska, G. 2007. A novel thermostable lipase from Basidiomycete Bjerkandera adusta R59: characterisation and esterification studies. Journal of Industrial Microbiology and Biotechnology 34:553-560.

Beres, C., de Nazaré, F. V. B., de Souza, N. C. C., Miguel, M. A. and Werneck, M. M. 2011. Tapered plastic optical fiberbased biosensor-tests and application. Biosensors and Bioelectronics 30(1):328-332.

Bora, L. and Kalita, M. C. 2007. Production and optimization of thermostable lipase from a thermophilic Bacillus sp. LBN 4. The Internet Journal of Microbiology 4(1):1-6.

Bradford, M. M. 1976. A rapid and sensitive method for the quantitation of microgram quantities of protein utilizing the principle of protein-dye binding. Analytical Biochemistry $72: 248-254$

Côté, A. and Shareck, F. 2010. Expression and characterization of a novel heterologous moderately thermostable lipase derived from metagenomics in Streptomyces lividans. Journal of Industrial Microbiology Biotechnology 37:883-891.

De Almeida, A. F., Tauk-Tornisielo, S. M. and Carmona, E. C. 2013. Acid lipase from Candida viswanathii: production, biochemical properties, and potential application. BioMed Research International 2013:1-10.

Dharmsthiti, S. and Ammaranond, P. 1997. Purification and characterization of lipase from a raw-milk yeast (Trichosporon asteroides). Biotechnology and Applied Biochemistry 26(2):111-116.

De Maria, P. D., Carboni-Oerlemans, C., Tuin, B., Bargeman, G. and Van Gemert, R. 2005. Biotechnological applications of Candida antartica lipase A: state-of-the-art. Journal of Molecular Catalysis B: Ensymatic 37:36-46.

Ginalska, G., Cho, H. Y., Cho, N. S., Bancerz, R., Kornilowicz, T., Leonowicz, A., Shin, S. J. and Ohga, S. 2007. Effect of culture conditions on growth and lipase production by a newly isolated strain, Geotrichum-like R59 (basidiomycetes). Journal of the Faculty Agriculture, Kyushu University 52:29-34.

Gutarra, M. L. E., Godoy, M. G., Maugeri, F., Rodrigues, M. I., Freire, D. M. G. and Castilho, L. R. 2009. Production of an acidic and thermostable lipase of the mesophilic fungus
Penicillium simplicissimum by solid-state fermentation. Bioresource Technology 100:5249-5254.

Hasan, F., Shah, A. A. and Hameed, A. 2006. Industrial applications of microbial lipases. Ensyme and Microbial Technology 39:235-251.

Hyde, K., Elsalam, K. A. and Cai, L. 2010. Morphology: still essential in a molecular world. Mycotaxon 114:439-451.

Iftikhar, T., Niaz, M., Afzal, M. and Rajoka, M. I. 2008. Maximization of intracellular lipase production in a lipaseoverproducing mutant derivative of Rhiropus oligosporus DGM 31: a kinetic study. Food Technology and Biotechnology 46:402-412.

Joseph, B., Ramteke, P. W. and Thomas, G. 2008. Cold active microbial lipases: some hot issues and recent developments. Biotechnology Advances 26(5):457-470.

Kakugawa, K., Shobayashi, M., Suzuki, O. and Miyakawa, T. 2002. Purification and characterization of a lipase from the glycolipid-producing yeast Kurtzmanomyces sp. I-11. Bioscience, Biotechnology, and Biochemistry 66:978-985.

Khoramnia, A., Lai, O. M., Ebrahimpour, A., Tanduba, C. J., Voon, T. S. and Mukhlis, S. 2010. Thermostable lipase from a newly isolated Staphylococcus xylosus strain; process optimization and characterization using RSM and ANN. Electronic Journal of Biotechnology 13:1-16.

Klis, F. M., Boorsma, A. and De Groot, P. W. 2006. Cell wall construction in Saccharomyces cerevisiae. Yeast 23:185-202.

Kumar, R., Mahajan, S., Kumar, A. and Singh, D. 2011. Identification of variables and value optimization for optimum lipase production by Bacillus pumilus RK31 using statistical methodology. New Biotechnology 28:65-71.

Kurtzman, C. P. 2000. Four new yeasts in the Pichia anomala clade. International Journal of Systematic and Evolutionary Microbiology 50:395-404.

Kwon, D. Y. and Rhee, J. S. 1986. A simple and rapid colorimetric method for determination of free fatty acids for lipase assay. Journal of the American Oil Chemists' Society 63(1):89-92.

Lee, G. N., Bae, J. H., Suh, M. J., Kim, I. H., Hou, C. T. and Kim, H. R. 2007. New finding and optimal production of a novel extracellular alkaline lipase from Yarrowia lipolytica NRRL Y2178. Journal of Microbiology and Biotechnology 17:1054-1057.

Li H. and Zhang, X. 2005. Characterization of thermostable lipase from thermophilic Geobacillus sp. TW1. Protein Expression and Purification 42:153-159.

Li W. F., Zhou, X. X. and Lu, P. 2005. Structural features of thermozymes. Biotechnology Advances 23:271-281.

Lin, E. S. and Ko, H. C. 2005. Glucose stimulates production of the alkaline-thermostable lipase of the edible Basidiomycete Antrodia cinnamomea. Ensyme and Microbial Technology 37:261265.

Mukherjee, S., Mukherjee, N., Saini, P., Gayen, P., Roy, P. and Babu, S. P. 2014. Molecular evidence on the occurrence of co-infection with Pichia guilliermondii and Wuchereria bancrofti in two filarial endemic districts of India. Infectious Disease of Poverty 3(13):1-10

Nadeem, M., Qazi, J. I. and Baig, S. 2009. Effect of aeration and agitation rates on alkaline protease production by Bacillus licheniformis UV-9 mutant. Turkish Journal of Biochemistry 34:89-96.

Namboodiri, V. M. H. and Chattopadhyay, R. 2000. Purification and biochemical characterization of a novel thermostable lipase from Aspergillus niger. Lipids 35(5):495-502.

Olusesan, A. T., Azura, L. K., Forghani, B., Bakar, F. A., Mohamed, A. K. S. and Radu, S. 2011. Purification, characterization and thermal inactivation kinetics of a nonregioselective thermostable lipase from a genotypically identified extremophilic Bacillus subtilis NS 8. New Biotechnology 28:738-745. 
Omar, I. C., Nishio, N. and Nagai, S. 1987. Production of a thermostable lipase by Humicola lanuginosa grown on sorbitol-corn steep liquor medium. Agricultural and Biological Chemistry 51:2145-2151.

Oslan, S. N., Salleh, A. B., Rahman, R. N. Z. R. A., Basri, M. and Chor, A. L. T. 2012. Locally isolated yeasts from Malaysia: identification, phylogenetic study and characterization. Acta Biocbimica Polonica 59:225-229.

Osumi, M. 1998. The ultrastructure of yeast: cell wall structure and formation. Micron 29:207-233.

Osumi, M., Yamada, N., Kobori, H., Taki, A., Naito, N., Baba, M. and Nagatani, T. 1989. Cell wall formation in regenerating protoplasts of Schizosaccharomyces pombe: study by high resolution, low voltage scanning electron microscopy. Journal of Electron Microscopy (Tokyo) 38:457-468.

Rathi, P., Bradoo, S., Saxena, R. K. and Gupta, R. 2000. A hyperthermostable, alkaline lipase from Pseudomonas sp. with the property of thermal activation. Biotechnology Letters 22:495498.

Ray, N., Ray, L., Srimani, B. N. and Chattopadhyay, P. 1999. Isolation and identification of alkaline thermostable lipase producing microorganism, cultural conditions, nutritional requirements and some properties of crude enzyme. Indian Journal of Experimental Biology 37:818-824.

Salameh, M. A. and Wiegel, J. 2007. Purification and characterization of two highly thermophilic alkaline lipases from Thermosyntropha lipolytica. Applied and Environental Microbiology 73:7725-7731.
Saxena, R. K., Ghosh, P. K., Gupta, R., Davidson, W. S., Bradoo, S. and Gulati, R. 1999. Microbial lipases: potential biocatalysts for the future industry. Current Science 77(1):101115.

Saxena, R. K., Sheoran, A., Giri, B. and Davidson, W. S. 2003. Purification strategies for microbial lipases. Journal of Microbiological Methods 52:1-18.

Shaw, J. F., Chang, C. H. and Wang, Y. J. 1989. Characterization of three distinct forms of lipolytic enzymes in a commercial Candida lipase preparation. Biotechnology Letters 11:779-784.

Smith, A. E., Zhang, Z., Thomas, C. R., Moxham, K. E. and Middelberg, A. P. 2000. The mechanical properties of Saccharomyces cerevisiae. Proceedings of the National Academy of Sciences of the United States of America 97:9871-9874.

Walker, G. M. 1998. Yeast physiology and biotechnology. pp. 103. England: John Wiley \& Sons.

Wang, J. R., Li, Y. Y. and Liu, D. 2015. Gene cloning, high-level expression, and characterization of an alkaline and thermostable lipase from Trichosporon coremiiforme V3. Journal of Microbiology and Biotechnology 25:845-855.

Wang, L., Chi, Z., Wang, X., Liu, Z. and Li, J. 2007. Diversity of lipase-producing yeasts from marine environments and oil hydrolysis by their crude enzymes. Annals of Microbiol 57:495-501. 